\title{
Transition from growth point policy to liberal urban development in Zimbabwe: The emergence of Ruwa Town, 1980-1991
}

\begin{tabular}{|c|c|}
\hline \multicolumn{2}{|c|}{$\begin{array}{l}\text { Mark Nyandoro } \\
\text { Terence T. Muzorewa }\end{array}$} \\
\hline \multicolumn{2}{|c|}{$\begin{array}{l}{ }^{1} \text { CuDyWat, North-West } \\
\text { University, South Africa }\end{array}$} \\
\hline \multicolumn{2}{|c|}{$\begin{array}{l}{ }^{2} \text { Department of Economic } \\
\text { History, University of } \\
\text { Zimbabwe, Zimbabwe }\end{array}$} \\
\hline \multicolumn{2}{|c|}{$\begin{array}{l}{ }^{3} \text { Department of Development } \\
\text { Studies, Midlands State } \\
\text { University, Zimbabwe }\end{array}$} \\
\hline \multicolumn{2}{|c|}{$\begin{array}{l}\text { Corresponding author: } \\
\text { Mark Nyandoro, } \\
\text { nyandoromark@gmail.com }\end{array}$} \\
\hline \multicolumn{2}{|c|}{$\begin{array}{l}\text { Received: } 04 \text { Mar. } 2017 \\
\text { Accepted: } 21 \text { July } 2017 \\
\text { Published: } 16 \text { Oct. } 2017\end{array}$} \\
\hline \multicolumn{2}{|c|}{$\begin{array}{l}\text { How to cite this article: } \\
\text { Nyandoro, M. \& Muzorewa, } \\
\text { T.T., 2017, 'Transition from } \\
\text { growth point policy to liberal } \\
\text { urban development in } \\
\text { Zimbabwe: The emergence of } \\
\text { Ruwa Town, 1980-1991', The } \\
\text { Journal for Transdisciplinary } \\
\text { Research in Southern Africa } \\
\text { 13(1), a426. https://doi. } \\
\text { org/10.4102/td.v13i1.426 }\end{array}$} \\
\hline \multicolumn{2}{|c|}{$\begin{array}{l}\text { Copyright: } \\
\text { ( 2017. The Authors. } \\
\text { Licensee: AOSIS. This } \\
\text { is licensed under the } \\
\text { Creative Commons } \\
\text { Attribution License. }\end{array}$} \\
\hline \multicolumn{2}{|c|}{ Read online: } \\
\hline 口ising & $\begin{array}{l}\text { Scan this QR } \\
\text { code with your } \\
\text { smart phone or } \\
\text { mobile device } \\
\text { to read online. }\end{array}$ \\
\hline
\end{tabular}

This article traces the transition from growth point policy to liberal development in the emergence of Ruwa Town in Zimbabwe from independence in 1980 to 1990/1991 when the town was declared an urban area under the administration of the Ruwa Local Board. In this period, there was a dire need for urban infrastructure (catalysed by a boom in urban population) in what was originally a commercial farming area. The article also analyses the role of privatepublic sector partnerships in promoting urban development. It contends that the establishment of Ruwa Growth Point and the town is closely associated with the rise of Private Land Developer Companies (PLDCs) in Zimbabwe. It further argues that all post-colonial established towns in Zimbabwe emerged out of the Government's direct investment initiated under the growth centre policy. However, the development of Ruwa was not influenced by the Government, but by a transition from the State-led growth point policy to a liberal urban development approach, which involved public-private partnerships in infrastructural development and facilitation of public amenities. The economic liberalisation process adopted by the country in the early 1990s weakened the growth point policy and gave private actors leverage to enter the urban land market, which was originally monopolised by the Government. The failure of the Government-led growth point policy and the local authorities' incapability to finance infrastructure development to improve service delivery forced the Ruwa Local Board to seek partnerships with PLDCs. The post-colonial State's acquiescence to draw on the services provided by PLDCs demonstrates that the companies were effective instruments in ensuring the success of the liberal urban development strategy.

\section{Introduction}

The article aims to investigate the changes that took place in the emergence of Ruwa Town ${ }^{1}$ on the periphery of Harare, the capital city of Zimbabwe, in the decade after independence. It questions whether there was a clear transformative transition in urban development in Zimbabwe from the 1980s Government-led growth point policy ${ }^{2}$ to the liberal private-public partnership development of the 1990s. The decade 1980 to $1990 / 1991$ is important to examine as it is directly related to the transition that culminated in declaring Ruwa as an urban area under the administration of the Ruwa Local Board (RLB). In this period, there was a dire need for urban infrastructure (catalysed by a boom in urban population) in what was originally a commercial farming area. In analysing the role of private-public sector partnerships in promoting urban development, the article contends that the establishment of Ruwa Growth Point and the town is closely associated with the rise of Private Land Developer Companies (PLDCs) in Zimbabwe. It further argues that all postcolonial established towns in Zimbabwe emerged out of the Government's direct investment initiated under the growth centre policy. However, the development of Ruwa was not merely influenced by the Government, but by a transition from the State-led growth point policy to a liberal urban development ${ }^{3}$ approach which involved public-private partnerships (PPPs) in infrastructural development and facilitation of public amenities. The economic liberalisation process adopted by the country in the early 1990s weakened and led to the failure of the growth point policy and gave private actors leverage to enter the urban land market, which was originally monopolised by the Government. The failure of the Government-led growth point policy and the

\section{Ruwa is situated $23 \mathrm{~km}$ from the central business district of the capital city of Zimbabwe, Harare.}

2.The growth policy was a strategy based on identifying potential areas for economic growth, which in both the colonial and post-colonial periods were envisaged to reduce rural-urban drift by providing employment and infrastructure for the people in the rural areas and periods were envisaged to reduce rural-urban drift by providing employment
to facilitate decentralisation of economic activities by creating small towns.

3.Liberal Urban Development has become the mode of production of urban space, not only in developed countries but also in developing nations. It is the dominant laissez-faire entrepreneurial urban policy with agent-oriented perspectives emphasising relations, networks and coalitions between governmental and commercial agents such as PLDCs. 
local authorities' incapability under economic liberalisation to finance infrastructure development to improve service delivery forced the RLB to seek partnerships with PLDCs. The post-colonial State's acquiescence to draw on the services provided by PLDCs therefore demonstrates that the companies were effective instruments in ensuring the success of the liberal urban development strategy in Zimbabwe.

Zimbabwe has experienced economic and social transition since 1980. In Ruwa's development, urban population growth in particular catalysed the demand for urban infrastructure in areas hitherto dominated by European agro-enterprises. The demand led to increased government presence in directing socioeconomic growth. However, faced with depleting financial resources, the Government gave in to the encroachment of the Ruwa farms by a private company, the Mashonaland Holdings Private Limited, whose operations were overseen by a Government-initiated Urban Development Corporation (UDCORP). The advent of Mashonaland Holdings witnessed the opening of floodgates to further encroachment onto the land by more private company developer agencies after 1987, mostly at the invitation of the RLB. From 1987 Ruwa shifted from a dependence on Government funding as ascribed by the growth point policy to a liberal approach that incorporated private land developers in the infrastructural development of the town after the adoption of economic structural adjustment policies.

This article illustrates the transition from growth point policy to a PPP-oriented urban development in Zimbabwe using the case of Ruwa Town. Based on whether there was a clear transition in urban development or not, it accounts for the establishment of Ruwa as a growth point within a commercial farming area by the Government of Zimbabwe in 1986. The article is divided into a background and three main sections. To illustrate the transition, the first major section examines the development of growth points in Zimbabwe and the emergence of Ruwa growth centre. It argues that growth point development was influenced by the Government's need to redress colonial established disparities between rural and urban areas and that the emergence of Ruwa was closely related to the growth point policy. The second section flips this paradigm in Zimbabwe in general and Ruwa in particular by arguing that economic challenges faced by Zimbabwe in the late 1980s prompted the rise of PLDCs after the Government had failed to sustainably fund the growth point policy. In the circumstances, the economic interventionist liberal policies adopted by the Government in 1990 catalysed the development of PLDCs, which in turn took over the responsibility of urban infrastructure provision formerly monopolised by the Government. The last major section discusses the factors that led to the establishment of PPPs in Ruwa. It concedes that soon after the establishment of the town, the RLB faced challenges in securing land and financial resources necessary for the area's growth and only PLDCs provided such resources. Thus, the main reason for the partnership between the RLB and PLDCs was to tap into each other's advantages in facilitating urban development.

\section{Literature review}

Urban development is not unique to Africa alone. It is a world-wide transformation induced by population growth and the demand for improved services. Some areas with limited population have witnessed stagnant growth. Others as a result of boundless increases in population have grown from growth pole centres ${ }^{4}$ into vibrant towns and cities, emphasising the connection between growth-point theory and urbanisation. For Dickovick (2011), in Africa, Latin America and developing parts of Asia, towns were the outcome of government decentralisation policies which, however, amounted to efforts at recentralisation of human settlements and services. ${ }^{5}$ Freund (2007) and Kessides (2006) have argued that the transition to urbanism in Africa is gathering pace and has implications for long-term economic and social development (Freund 2007; Kessides 2006). The World Bank (2013:3) has predicted that $50 \%$ of Africa will be urbanised by 2030 .

While Africa is rapidly becoming urbanised, with half of its population living in urban agglomerations, Beall, GuhaKhasnobis and Kanbur (2010) and Dillinger (1994) caution on the necessity of infrastructure for the improvement of urban service delivery. Historically, infrastructure development was the responsibility of governments. However, the onset of financial crises crippled government capacity, which in turn meant urban residents constituted a limited tax base for funding the provision of viable and expansive public services. Consequently, emerging urban centres have increasingly found it necessary to engage private development partners in order to meet the rising demand for housing, electricity, industrial infrastructure and social services such as water, education, health and sanitation. Scholarship, as explained by Abrams (1964a, 1964b), Aldrich and Sandhu (1995), Hardoy et al. (1990), Hauser and Schnore (1967), Howard (2003:197-235), Stren and White (1989) and Stren (2004:30), confirms the necessity for improved service provision in these fields. Improved services affect urban residents in a positive way.

In Zimbabwe ${ }^{6}$ literature on growth point development and associated service delivery systems has been written by Rukuni, Schonker and Muzari (1993), Helmsing (1990), Wekwete (1987) and Manyanhire et al. (2009). Rukuni et al. in particular analyse how the process of urbanisation was linked to the growth point policy and the late 1970s policies on rural development or rural service centre theory in Zimbabwe. The genesis of the growth point policy was meant to stop or minimise rural-urban migration by creating rural

4.The theory states that growth manifests itself in an area or point from which it is then transferred to other regions. See Wekwete (1991:190)

5.Decentralisation is 'the economic development of growth points outside the major cities with particular reference to commercial and industrial activities'. Decentralisation equated to community development as a strategy for democratic Decentralisation equated to community development as a strategy for democratic governance, which accords local communities responsibility over their own development. It seeks to transfer power from a central authority to local or grassroots authorities. It is a regional development policy aimed at promoting wider and more balanced distribution of economic activity in the national space. See Howman (1969:3-8), Brand (1991) and Nyandoro (2007:132).

6.Before independence, Zimbabwe was known as Southern Rhodesia, later Rhodesia 
service centres, growth points and business centres to absorb people looking for jobs in the cities (Rukuni et al. 1993:11). For these scholars, between the 1960s and 1970s the growth point policy stimulated private sector investment in small rural towns to decentralise services (Munzwa \& Jonga 2010:120). This was the context in which small towns like Ruwa in Zimbabwe and the involvement of the private sector and private land developers in these towns emerged.

Wekwete argues that since the 1950s, growth centre planning has been one of the key features of regional development planning in the world (Wekwete 1991:189). It was initially linked with industrial development and economic growth, but has increasingly shifted towards the provision of basic services. For Nyandoro (2007:157), something along these lines was therefore attempted in Zimbabwe, especially after the colonial government had realised in the 1960s that there were vivid signs of underdevelopment in the communal areas, ${ }^{7}$ which represented poorly developed areas with weak links to the urban centres of the country. As a result, since independence in 1980, the Government took a leading role in developing and uplifting rural growth points like Ruwa and Chitungwiza, which were turned into towns (Wekwete 1988:5). The development of small towns helps to demonstrate the link between Ruwa and the growth centre theory. However, the Ruwa case goes beyond the growth point policy enunciated by the Government by moving towards a clear partnership approach to urban development.

The transition of Ruwa from growth point-oriented development to private-public partnerships-led development can be illustrated by the operation of PPPs discussed by Van der Veen (2009:89). In his work, he highlights the operations of international urban projects, which involved PPPs in London, New York and Amsterdam. He examines the content of contracts and agreements between the public sector (city administrators) and the private property developers in these big Western cities in a way that has interesting parallels with what happened in Ruwa. His work, though focusing on cities in the industrial developed world, is vital in analysing the way PLDCs operated in Ruwa on the basis of contractual agreements or permits. Studying Ruwa, however, goes beyond an analysis of partnership agreements and an examination of the activities of PLDCs in relatively betterfunded European metropolitan centres. The growth of Ruwa shows the transition from the growth point policy to liberal urban development in Zimbabwe (southern Africa) where PLDCs played a crucial role in the expansion of the town.

In Zimbabwe, PLDCs operated within the context of urbanisation and land markets. Marongwe, Mukoto and Chatiza (2011:8) have defined urban land markets in the country as the platform for interaction among land buyers, land developers and retailers, as well as a process of registration of land and property. They emphasise governance of urban land markets. For them, land markets are the framework that govern planning and land administration in 7.In the colonial period, communal areas were known as Tribal Trust Lands. the country. Private land developers who were actively involved in infrastructure development in Ruwa were the main actors in land markets. Understanding the urban land market helps to appreciate the importance of PLDCs in Zimbabwe's urban development. However, unlike Marongwe et al., our study goes beyond the governance of urban markets and gives a detailed account of the rise of PLDCs in Ruwa and their role in infrastructure development in a context of no or limited government funding.

To address the broad issue of infrastructure provision and the attendant shortage of government funding and active State engagement, the emerging Ruwa Town of Zimbabwe, in the decade between the 1980s and 1990s, made valiant efforts to lure private company investment into an area which originally was a White commercial farming hinterland. This marked the beginning of the change from growth point policy to liberal urban development in Ruwa. The emergence of Ruwa Town (1980-1991) is thus a case of transition from State-led growth point policy to PPP-oriented urban development in Zimbabwe.

Ruwa Town near Harare's central business district was established as a growth point within a commercial farming area by the Government of Zimbabwe in $1986 .{ }^{8}$ Prior to that date, it depended on Harare and the Government for essential services such as water supply and funding. However, in 1987 Ruwa shifted from a dependency on Government funding as ascribed by the growth point policy to a liberal approach which incorporated PLDCs in the infrastructural development of the town. PLDCs are companies that subdivided land which they owned or purchased from individual private owners into urban residential and industrial plots in line with permits given to them by the Government or local authorities for the purpose of making profit (Independent European Development Portal 2012). They serviced the land by constructing offsite and onsite infrastructure, which included water supply and sewerage facilities (Ruwa Local Board 2011b:1). The developers also developed road networks and other public amenities in accordance with the provisions of the land development permits issued by the Town Council's planning authority. In 1991, Ruwa became an urban centre administered by the RLB and had a population of over 25000 people (Central Statistics 2014). The RLB was the local administrative arm of the Ministry of Local Government, Rural and Urban Development. This article examines the emergence of Ruwa. It argues that the town adopted a PPP approach to development because the Local Authority or RLB had limited financial resources and land needed to sustain the expansion of the town commensurate with a growing population. The RLB opted to partner with PLDCs, which had better financial resources to lead development. The rise of PLDCs is therefore central to the emergence of Ruwa beginning in 1980 when the growth point policy which existed since the 1950s was first applied to post-colonial

8. Ruwa was established in the 1890 s as a commercial farming area and its first local authority, the Bromley-Ruwa Rural Council (BRRC) was set up in 1950. After 1980 authority, the Bromley-Ruwa Rural Council (BRRC) was set up in 1950. After 1980,
when Zimbabwe got its independence, the BRRC changed its name to Goromonzi Rural District Council. See Ruwa Local Board (2011b:6). 
urban development in Ruwa. ${ }^{9}$ The year 1991 is appropriate as a cut-off point for this article because it marked the full integration of PLDCs into the development of Ruwa, resulting in the area, which began as a growth point, earning urban status.

\section{Development of growth points in Zimbabwe and the emergence of Ruwa Growth Centre}

The growth centre policy in Zimbabwe emerged as a major feature of the colonial Government. The colonial realisation of the problem of underdevelopment in the rural areas led to the official adoption of the growth point policy in the late 1960s/1970s. The policy was premised on creating 'African towns in African areas', to generate employment for Africans and halt the influx to 'European towns' (Hansen 1972; Heath 1978; Norcliffe, Freeman \& Miles 1984; Nyandoro 2015; Richardson 1978:123; Wekwete 1987:11, 1991:195). It was designed to prevent the migration of Africans into urban areas not only through generating employment in rural areas but also through establishing growth points in those areas to provide basic services for Africans.

The period that followed the Unilateral Declaration of Independence (UDI) by Rhodesia in 1965 up to 1979 was influential in the growth and expansion of growth points and urban areas. When Rhodesia declared UDI, proclaiming independence from Britain, it faced international trade sanctions approved by the United Nations and there was a drastic reduction of imports of consumer goods. The trade sanctions forced the colonial Government to substitute imported consumer goods with locally manufactured ones (Kapungu 1973; Losman 1978:333; McKinnell 1969; Wekwete 1994:34). More industrial infrastructure than during the Second World War ${ }^{10}$ was developed in cities such as Salisbury (now Harare) and Bulawayo. Consequently, additional African labour was required in the urban areas, and this compelled the Government to increase housing construction as it was apparent that Africans were becoming permanent residents in the city where their residency had been restricted under colonial laws.

Towards 1979, the Liberation War reached its apex. ${ }^{11}$ The urban population grew rapidly because many people fled the rural areas as a result of the war. The Rhodesia Government was so overwhelmed by the urban influx caused by the war that it failed to effectively apply the African urban restriction laws (Patel 1988:3). The influx of Africans into the urban areas resulted in the development of squatter camps in some towns, for example the Chirambahuyo settlement in Chitungwiza (Patel 1988:3). The Government seemed to turn a blind eye on the urban African population boom as it

9.Although the growth point theory existed since the 1950 s, it was not practically applied until the late 1960s/1970s in some cases and not until 1980 in other cases.

10.Just like in the period after the Second World War, the local manufacturing industry blossomed after UDI.

11.For detail on the Guerrilla War, see Mtisi, Nyakudya and Barnes (2009) and Kriger (1992). concentrated on pacifying African nationalism and containing the Liberation War.

The high rate of rural-urban drift by Africans in the late 1970s forced the colonial Government to intensify the development of rural or growth centres in a bid to stop African inflows into the urban areas. In 1978, the Government introduced a policy document, named the Integrated Plan for Rural Development (IPRD). The IPRD planners nominated 10 centres in the rural areas of Zimbabwe to be established as growth points. The 10 growth centres were Gutu, Mushumbi, Chisumbanje, Mataga, Jerera, Murewa, Wedza, Maphisa, Sanyati and Nkayi (Manyanhire et al. 2009:509). In the same year, Statutory Instruments 57 and 58 relating to income tax and sales tax, respectively, provided for industrial decentralisation incentives (Wekwete 1988:7). Such provisions included a reduction in revenue tax for industrial companies that moved to designated growth points (Wekwete 1988:7). Companies operating in such areas were also exempted from capital equipment purchase tax. Two years after the implementation of the IPRD and the tax legislation, the country gained independence and a new Government came into power.

The new Government inherited a stratified dual economy with very poor rural settlements and better developed urban centres. There was need for the Government to redress colonial imbalances through the Growth with Equity (GWE) policy. GWE was an overall macroeconomic policy framework based on empowering the formerly disadvantaged African population. It also formed the foundation of the growth point policy after independence. In the urban areas the Government introduced the Home Ownership Policy in 1981. This policy was part of the GWE framework and was aimed at enabling Africans to own houses in the urban areas. Under the policy, $90 \%$ of all houses in African townships were sold to sitting tenants (Paradza 2005:2). This was one way of empowering urban Africans.

After independence there was clear Government intention to increase the number of growth points. In 1981 the Department of Physical Planning identified 55 potential growth points and 450 rural service centres for development into growth centres (Munzwa \& Jonga 2010:129). The growth points were created to facilitate decentralisation or devolution of power under the GWE policy. In the Zimbabwean context, growth points were areas considered by the Government to have potential for development in the future and because of that they required support from the Government to enhance growth. In 1986, the Government established the UDCORP which was created under the provisions of the Urban Development Corporation Act of the same year, which became the basis for the establishment and emergence of Ruwa as a growth point. Ruwa had existed as a rural area under the Goromonzi Rural District Council between 1890 and 1986. ${ }^{12}$ The corporation formed in 1986 had a mandate to create

12.Ruwa operated as a growth point from 1986 to 1990. In 1990, it was an urban area under the administration of the Ruwa Local Board (RLB) which was set up in September the same year. It however only gained town status in 2008. 
employment and encourage the establishment of industries in the growth centres (Wekwete 1988:7). The UDCORP was part of Government effort to catalyse the development of growth points and urban areas in Zimbabwe.

In 1987, the Government of Zimbabwe stepped up the tax incentives through a publication entitled 'Tax Incentives for Businesses in the Growth Point Areas' (Rukuni et al. 1993:11). The Government reduced corporate income tax and gave rural companies import tax rebates. Companies located in growth points were given a corporate tax allowance on construction costs for developing industrial complexes (Rukuni et al. 1993:11). These tax incentives which consolidated the Government's industrial decentralisation thrust were meant to lure investors to the designated growth points. The growth point policy, however, faced challenges soon after implementation. Some areas selected as growth points became characterised by retarded and stagnant growth. These included Mount Darwin, Chipinge, Lupane, Mudzi, Uzumba Maramba Pfungwe, Mwenezi, Rushinga and Tsholotsho (Chirisa, Dumba \& Dube 2013:44). In spite of the tax incentives, most large-scale industries did not relocate to the growth points with the exception of a few that were located in centres near Harare such as Ruwa and Juru.

The implementation of the growth point policy was disturbed by economic challenges faced by Zimbabwe in the 1990s because of the Economic Structural Adjustment Programme (ESAP). Capital investments in growth points and the provision of social services (water, education, health and transport) by the Government proved costly. In 1991 the Government embarked on ESAP as a way to scale up economic growth in the country. The country decided to seek financial inflows from the International Monetary Fund (IMF) and the World Bank in order to undertake economic restructuring to improve the country's economic situation (Alderso 1998; Chakaodza 1993:16). The two multilateral aid institutions required the Government to implement liberal economic policies before funding was disbursed. Within this neo-liberal package of policies was the decontrolling of prices, deregulation of trade, devaluation of the local currency, the removal of subsidies, reduction of public expenditure, wage restraints, removal of tariffs, encouragement of foreign investment, the removal of administrative controls and privatisation of key sectors of the economy (Chakaodza 1993:16). Structural Adjustment sought to reduce Government expenditure on social services and to redirect expenditure towards investment in the manufacturing, agricultural and mining sectors (Mlambo 1997; Nyandoro 2007; Zhou \& Zvoushe 2012:216). This was in a bid to promote individual entrepreneurship in all sectors of the economy as advocated by the neo-liberals.

In turn, ESAP prompted Ruwa, which was experiencing infrastructural challenges, to adopt a neo-liberal approach. The approach was meant to solve the town's infrastructural development problems caused by lack of finance because the Government had cut expenditure on social services and growth point development. Besides, residents constituted an inadequate tax base for funding the required public infrastructure. As a result, Ruwa increasingly looked to the public-private sector partnership to provide the required infrastructure, hence engaging PLDCs in a relationship which started in 1980.

\section{Rise and role of Private Land Developer Companies in Ruwa (Zimbabwe), 1980-1991}

There are a series of events that led to the rise of PLDCs in Zimbabwe. With the increase of urbanisation in the whole world during the 20th century, both Western capitalist and communist countries adopted PLDCs in urban development. Urban liberalism and privatisation were sometimes reluctantly implemented by most communist countries. Countries like China and Russia, which resented economic non-interventionist policies, however, adopted a liberal approach to urban development in the 20th century. Ding and Lichtenberg (2009:1) note that the expansion of Chinese cities has been catalysed by the creation of a secondary market, which gave the private sector long-term leasing rights to urban land. The private sector's intervention policies have accounted for the rapid expansion of cities like Shanghai, Guangdong and Guangzhou in China (Ding \& Lichtenberg 2009:1). Similarly, in Zimbabwe demands for democratisation and liberal processes led to the rise of PLDCs and the development of Ruwa Town.

Private urban land developers in Zimbabwe consisted of land developer companies, unit trusts, building societies and life insurance companies. According to Marongwe et al. (2011:36), private institutional investors were responsible for about $85 \%$ of all property and land development in Zimbabwe's urban areas. The activities of building societies can be traced back to the enactment of the Building Societies Act in 1951. However, building societies that operated during the colonial period mainly financed White community infrastructure development leaving out African areas. Building societies such as Founders Building Society and the Central African Building Society (CABS) were not involved in developing land for urban purposes. Rather, they just financed European housing development schemes. In the independence era, building societies became the major private sector companies involved in land development. Building societies such as CABS, the Commercial Bank of Zimbabwe Building Society and ZB Building Society were directly involved in the servicing of land, development of offsite infrastructure (water and sewer) and the construction of public amenities like schools, hospitals and recreational facilities in the urban areas. ZB Building Society, for example, was a major land developer in Ruwa Town during the postcolonial period.

Before independence, colonial legislation did not allow PLDCs to thrive. There was generally low urban population resulting in a restricted land market. The colonial city was only designed to sustainably house the white population. 


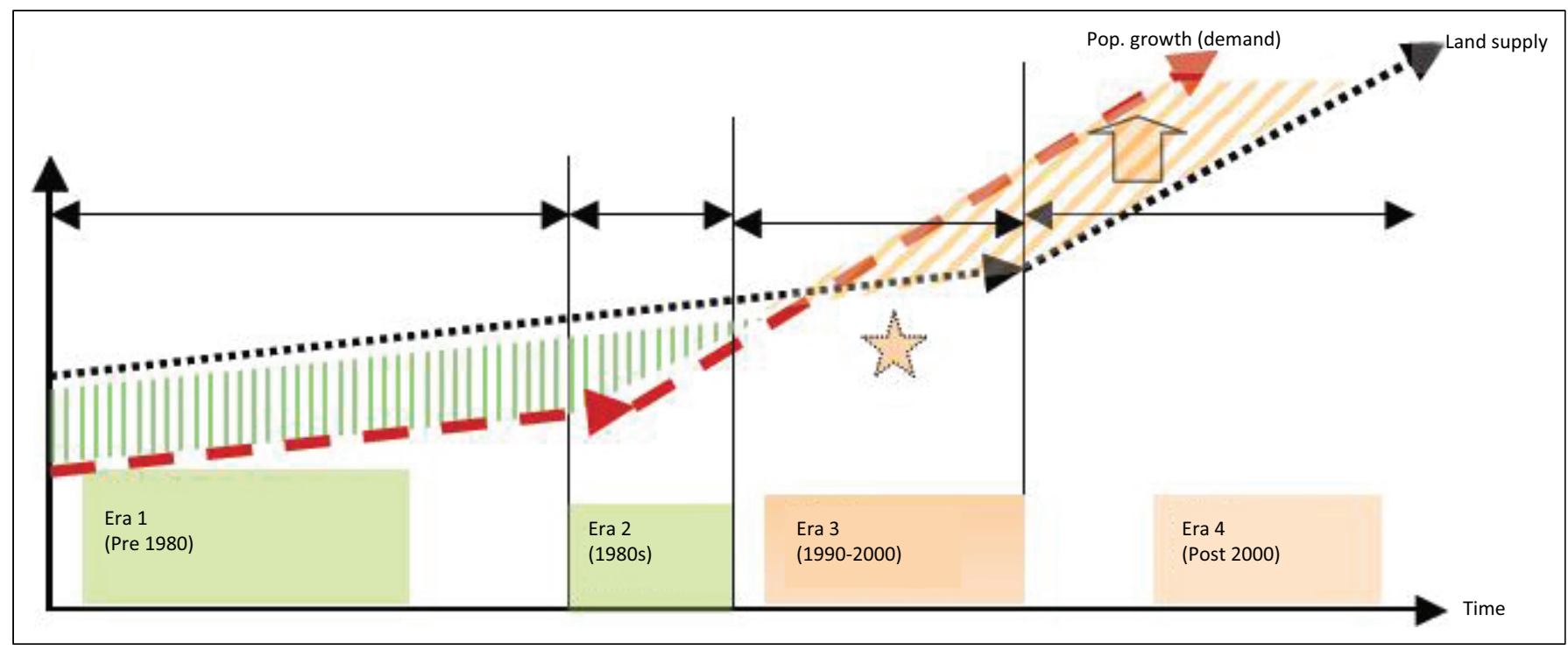

Source: Marongwe et al. 2011:10

FIGURE 1: Land supply and demand in Zimbabwean urban areas.

The Government was not concerned about building and improving urban African housing because Africans were viewed as temporary residents of the city. Such colonial legislation not only alienated Africans from the towns but also decongested urban space. For White officials, there was no urge for the expansion of African housing because the majority of the African population had been condemned to the rural areas.

The need to expand urban land arose because of the demand prompted by high rural-urban migration in the wake of independence. As the urban population grew, it became apparent that the Government and local authorities were limited in their ability to provide adequate accommodation and other services. This provided an opportunity for the emergence of PLDCs before and especially when the economy was liberalised through the implementation of ESAP in 1991. Because one of the main tenets of ESAP was to promote a liberal market and private investment, the programme created a good environment for PLDCs to operate. Individual residents started to align themselves with the private sector in an endeavour to access the services they hitherto lacked but required. At the same time, 'the Government's role [in the circumstances] changed from that of a provider to that of an enabler of human settlement development' (Chirisa 2013:104). The Government had to create a platform where the market could operate through the encouragement of cooperation between the public sector and the private sector. During ESAP (1991-1995) there was, thus, a rise in the activities of PLDCs and the private sector in Zimbabwean land markets. The period up to 1996 witnessed a rapid expansion in the housing market in Ruwa, driven by PLDCs (Chirisa 2013:104). In light of this, by liberalising the land market, ESAP created a flourishing environment for PLDCs to operate. The land market blossomed because of the increased demand for urban land in the post-colonial era, as illustrated in Figure 1.
Figure 1, although it goes up to 2000, demonstrates how the increasing population in urban areas outgrew the demand for land between independence in 1980 and 1990. The population boom resulted in a desperate need for urban serviced land. The local authorities' failure to meet the demand for serviced land partly before and as a result of ESAP, therefore, prompted the rise of PLDCs in Ruwa.

The results of ESAP were disastrous in almost all sectors where the Government provided services such as education, health and public housing. By default, this resulted in the private sector taking over some public service responsibilities. The removal of Government subsidies from local authorities resulted in poor service provision in areas ranging from infrastructure development and health services to education. This affected urban livelihoods. ${ }^{13}$ The private sector, because of its relatively sound financial status, started to provide services previously provided by the Government and local authorities. These services included the construction of housing, health and education facilities. Because the RLB faced shortages of funds to develop infrastructure and skilled manpower especially after the removal of Government subsidies, it established a partnership with the PLDCs (Chirisa 2000:30). The removal of Government subsidies forced local authorities to look for alternative funding and one avenue was incorporating PLDCs into the development of the town.

\section{Road to partnership between Ruwa Local Board and Private Land Developer Companies}

When the first local authority, the RLB, was created in 1990, it opted for partnership with PLDCs in an endeavour to promote the growth of the newly established town. In the partnership, the PLDCs provided the land and constructed

13.For detail on the impact of ESAP on Zimbabwe, see Chakaodza (1993:4-23) and Potts (2000:879-910). 
onsite and offsite infrastructure on a Build and Transfer Agreement. Under the Build and Transfer Agreement the PLDCs constructed onsite and offsite infrastructure, which included roads, water and sewerage reticulation systems and other supporting public amenities. The developers then handed over the infrastructure to the local authority after completing construction. PLDCs benefited from the opportunity from the Council to subdivide their land and sell it for profit and the Build and Transfer was part of endowments they paid to the Local Authority. The reason for the partnership between the RLB and PLDCs was to tap into each other's advantages. Most of the land in Ruwa was privately owned and the Local Authority had limited land for town expansion. The companies had access to land, which they bought from commercial farmers and other plot holders. In addition to land scarcity, the Local Authority did not have enough funding to initiate development projects in the area except the limited grants administered by the central government. The grants were to assist local governments with capital investments. Hence, the Authority needed external financial investment from the PLDCs. Bedevilled by challenges related to land and finance, the RLB, therefore, sought a partnership for development with the private sector. In spite of the challenges faced by the Authority, the two needed each other as private developer companies also relied on the RLB for securing land development permits.

The development of the partnership can be traced back to the time Ruwa was designated a growth point in 1986. At that time, the UDCORP was given the mandate to administer the area. However, it faced difficulties in securing land for the development and expansion of the growth point while Mashonaland Holdings Private Limited owned land, which was a large farm belonging to Terence Hardy, the Holdings Company chairman (Muzorewa 2012:63). It was the Mashonaland Holdings land that relieved the UDCORP from its land scarcity frustrations. With the acquisition of that land, development kicked off in Ruwa. Nevertheless, the RLB, which was established after the UDCORP in 1990, inherited only $1 \%$ of the land under its jurisdiction. The $1 \%$ was acquired through land endowments after subdivision permits were issued to Mashonaland Holdings by the Department of Physical Planning of the Ministry of Local Government, Rural and Urban Development (Ruwa Local Board 2011b:6). This acquisition was important because expansion of infrastructure and service institutions in urban areas was based on land available. Land was generally a scarce commodity in Ruwa before the partnership with Mashonaland Holdings and other commercial farmers.

Since the inception of Ruwa initially as a growth point, the land issue resulted in a number of problems, some of which included the paucity of affordable housing schemes for the low-income earning groups, the inability of the RLB to accommodate small-to-medium entrepreneurs, and social facilities and amenities such as churches and recreational facilities (Muzorewa 2012:51). As a result of land shortages, the Local Authority failed to secure land for a formal refuse
TABLE 1: Land use in Ruwa Town.

\begin{tabular}{lc}
\hline Existing development & Percentage of total area \\
\hline Low-density residential & 40.74 \\
Industrial & 24.62 \\
High-density residential & 32.01 \\
Commercial & 2.23 \\
Institutional & 2.48 \\
Open space for development & 6.12 \\
Total & 100 \\
\hline
\end{tabular}

Source: RLB 2011b

dump site and resorted to using a private dump, which was neither properly planned nor formally acquired (Ruwa Local Board 2011b:6). Furthermore, there was no land to establish a sewerage treatment plant and Ruwa relied on a plant in neighbouring Epworth (Davison 2005:57). Given a situation where the Local Authority did not have sufficient land (and most of it was privately owned), it was difficult for it to take full control of development-oriented activities and planning of the built environment. Public planning was limited as the town planner could not plan on land that did not belong to the council. Because of land scarcity for town development as illustrated in Table 1, the Ruwa Local Authority collaborated with several PLDCs, such as Mashonaland Holdings Private Limited, Chipukutu Properties, Zimbabwe Reinsurance Corporation and others, ${ }^{14}$ that had access to private land as land scarcity was seen as one of the factors that retarded the growth of Ruwa.

Table 1 is an illustration of land usage. It demonstrates that most of the land in Ruwa Town was already developed with only $6.12 \%$ of the area remaining for future development. Land used for commercial centre development only amounted to $2.23 \%$ of the total and this did not tally with the huge land use proportion of $72.75 \%$ taken by residential plots. In order to redress the imbalance in land usage, the Local Authority had to seek more land through partnerships with the PLDCs.

There were also disparities between big and small local authorities. These were not entirely based on possession of land. In Zimbabwe, big local authorities like the Harare City Council acquired significant autonomy to perform their functions through the decentralisation policy, which gave them the power to establish income-generating entities within the Council area. However, smaller authorities such as Ruwa had less capacity to exercise autonomy because of their inability to generate funds. The main sources of revenue for local authorities included sales of water, tariffs for services rendered and assessment rates on properties. Other revenue sources included public amenities grants as well as road grants, loans for capital works from central Government through the National Housing Fund for housing development, the General Loan Fund for other infrastructure like water and sewerage reticulation and loans from the open market (De Visser, Steytler \& Machingauta 2010:37). Although this

14.Since 1987, there were nine major developers operating in Ruwa. These were Mashonaland Holdings Private Limited, Chipukutu Properties, Zimbabwe Reinsurance Corporation, Wentspring Investments Private Limited, Damofalls Reinsurance Corporation, Wentspring Investments Private Limited, Damofalls
Investments Land Developers, Fairview Land Developers, Zimbabwe Housing Company, Barochit Property Developers and Tawona Gardens Private Limited. 
list may look as if the council in Ruwa had a vast pool of revenue sources, the council faced many challenges in getting revenue from these sources. Its largest source in terms of managing council costs has been support for a grants system administered by the central government to help local governments plan capital investments. The assistance, however, did not quite materialise in a financially difficult economic environment especially under ESAP.

The Local Authority therefore generally lacked the ability to create income-generating projects to sustain development in the area. Most big local governments in Zimbabwe like the Gweru City Council (Midlands Province) did not entirely depend on the Government and tariffs for capital revenue, but had alternative revenue sources in the form of enterprises. The Gweru local authority owned revenue-generating operations, for instance the Go Beer Brewing Company (Mika 2010:15), which was run by an independent board with directors appointed by the council. It produced and retailed traditional beer, reared livestock and grew maize on the council's farms (Mika 2010:5). In contrast, Ruwa Town had no such income-generating ventures as it failed to establish economic enterprises; hence, it relied on rates collection, which did not provide sustainable revenue as some ratepayers defaulted. In light of this, Ruwa local authorities thus opted to partner with PLDCs to complement their limited sources of revenue.

The economic meltdown in Zimbabwe exacerbated by ESAP in the 1990s had a large bearing on Ruwa's incapacity to fund its development projects. ESAP restricted the Government from giving substantial grants and subsidies to local authorities. The situation worsened following the political and economic fall-out with bilateral and multilateral institutions like the WB and IMF. The two stopped financing urban councils because of tensions between the ruling party (ZANU-PF) and the international donor agencies. The poor relations between the Zimbabwean Government and the donor community resulted in economic sanctions from the moneylenders and this affected Ruwa and other urban councils' sources of revenue. Because the Government had been starved of loans from the multilateral aid donors, it could not continue to fund local authorities, which traditionally received grants and loans from the Government. This hampered development in the area and forced the Ruwa local authorities to search for partnerships with land developers.

The partnerships, however, did not signal the end of Ruwa's problems. The local authorities' revenue crisis was still worsened by poor payment of rates and the enforcement of charges and tariffs on ratepayers. In the circumstances, the Local Authority used the water supply termination method (water cuts) to force and make people pay up their service charges, but most residents dug wells to evade the council measures and, hence, were no longer threatened by water disconnections. Nevertheless, James Gutu (Ruwa resident), in an interview on 11 February 2014 noted that most residents blamed the Local Authority for not supplying water to their households and argued that was the reason why they deliberately refused to pay rates and council charges. This meant that the water termination method used by the Local Authority to enforce revenue collection from the residents was not effective. The town secretary, in an endeavour to collect the debts owed by residents, sent 'debt final warning' letters to residents, but in spite of some residents receiving more than three such letters, they still did not comply (Ruwa Local Board 2011a). The warning statements were not followed by any revenue collection enforcement measures and because of this, most of the residents in debt tended to ignore the warnings. The lack of an effective way to collect revenue from rate payers in debt resulted in loss of revenue by the Council.

On the whole, the majority of urban councils in Zimbabwe charged subeconomic rates and service fees because of the Government's interventionist regulations on council charges. The Minister of Local Government and National Housing was the chief determiner of council rates and tariffs (Chirisa \& Jonga 2009:3), so urban councils could not increase surcharges or rates without permission from the Ministry. The Regional Town and Country Act of 1976 mandates the Ministry to approve local authorities' budgets, and increases of tariffs and supplementary charges (The Regional Town and Country Act 1976). The regulation of council service charges was a political populist control weapon used by the Government without considering its detrimental effects on service delivery in the urban areas. According to the RLB Financial Director, Mhiti, in an interview on 9 March 2012, Ruwa was bedevilled by Government regulation of water charges, where the town council was forced to charge 40 cents per cubic meters $\left(\mathrm{m}^{3}\right)$ of water to its consumers, while the council purchased water for 47 cents per $\mathrm{m}^{3}$ from Damofalls water treatment plant. This meant that the RLB made a loss of about 7 cents per every $\mathrm{m}^{3}$ of water they supplied to consumers. Mhiti also revealed that this was the case with refuse collection where the RLB paid an undisclosed sum of money per month to the Goromonzi Rural Council for a dump site, but charges for refuse collection could not cover all the expenses involved. Charging service fees that were not proportional to the amount of money invested in service delivery made it economically unviable. Government control and determination of charges was uneconomic and made the local authorities in Ruwa to partner with private developers who had financial capacity to compensate the losses made through the Government tariff regulation policy.

Linked to the shortages of finance was the water supply and sewer reticulation challenge. Ruwa failed to cater for residents in the provision of water and sewer reticulation services. The population boom had resulted in an increased demand for water, making it difficult for the local authorities to satisfy the demand for water and reticulation services. The water pumping mains which delivered water to Ruwa in the year 1991 had been designed in 1986 only to deliver $133 \mathrm{~m}^{3}$ of water per day (Davison 2005:57). The demand for water in Ruwa in 1991 was $1900 \mathrm{~m}^{3}$ per day, leaving a deficit of about 
$1767 \mathrm{~m}^{3}$ per day (Davison 2005:57). The problem that affected the system of water distribution in Ruwa had more to do with demand outstripping supply than the ageing of the system. Clearly, the Local Authority could not solve the water shortages on their own because of financial constraints. That is why they opted to partner with the PLDCs in order to ease the situation. Ruwa was, therefore, outstanding for involving PLDCs in the development of the town on the basis of a PPP between the RLB and the PLDCs.

\section{Conclusion}

The article finds that after independence up to 1991 the changes that took place in the emergence of Ruwa Town in Zimbabwe indicated a major transition in urban development. This was a change from State-led growth point policy to liberal urban development on the basis of the activities of PLDCs. The article therefore concludes that the transition from the growth point policy to liberal urban development in Zimbabwe explains not only the emergence of Ruwa Town but also the leading corporate role taken by PLDCs towards facilitating infrastructure development at a time the Government was facing cash flow (inflow and outflow) problems. It demonstrates that Ruwa and PLDCs rose because of a dire need for urban facilities in what was originally a commercial farming area. The need for urban infrastructure was catalysed by a boom in urban population during the post-colonial era. Economic liberalisation adopted by the country in the 1990s gave private actors leverage to enter the urban land market, which was originally monopolised by the Government. Upon entering the land market in Ruwa from 1987, the companies bought land from commercial farmers, which they developed into residential, commercial and industrial areas before selling it to individuals and other entrepreneurs and surrendering the administration of the land to the Ruwa Local Authorities. Guided by land development permits issued to the developers under the provisions of the Regional Town and Country Act of 1976, the PLDCs played a critical role in infrastructural development and facilitation of public amenities such as roads, sewerage and water systems, educational institutions, electricity and health facilities.

Developer companies were, thus, the most appropriate vehicles for urban development in Ruwa. The transition in development from the growth point policy to a PPP approach was a way to ensure the survival and further development of the town as poor economic conditions in post-colonial Zimbabwe had made it impossible for the Government and local authorities to finance urban growth as proposed under the growth point policy. ESAP clearly restricted Government funding towards growth centre development; hence, Ruwa sought partnerships with PLDCs whose financial capacity was higher than that of the Government and the council combined. In addition, Ruwa benefited from the land acquired from PLDCs because the RLB did not have land for the town's expansion. By moving from the traditional growth point approach to a liberal approach involving private-public partnerships Ruwa, therefore, offers unique insights into modern urban development in Zimbabwe.

\section{Acknowledgements}

The authors would like to thank CuDyWat.

\section{Competing interests}

The authors declare that they have no financial or personal relationships which may have inappropriately influenced them in writing this article.

\section{Authors' contributions}

M.N. and T.T.M. contributed equally to the writing of this manuscript.

\section{References}

Abrams, C., 1964a, Man's struggle for shelter in an urbanizing world, MIT Press, Cambridge, MA.

Abrams, C., 1964b, Housing in the modern world, Faber and Faber, London.

Alderso, M., 1998, 'Women and children first: Adjustment, gender and food security in Zimbabwe', Review of African Political Economy 1, 4-23.

Aldrich, B.C. \& Sandhu, R.S. (eds.), 1995, Housing the urban poor: Policy and practice in developing countries, Zed Books, London.

Beall, J., Guha-Khasnobis, B. \& Kanbur R. (eds.), 2010, Urbanisation and development Multidisciplinary perspectives, Oxford University Press, Oxford. https://doi. org/10.1093/acprof:oso/9780199590148.001.0001

Brand, C., 1991, 'Will decentralisation enhance local participation?', in A.H.J Helmsing (eds.), Limits to decentralisation in Zimbabwe: Essays on the decentralization of government and planning in the 1980s, pp. 79-96, Institute of Social Studies, The Hague.

Central Statistical Office, 2014, Population Unit, CSO, Harare.

Chakaodza, A.M., 1993, Structural adjustment in Zambia and Zimbabwe: Reconstructive or deconstructive?, Third world Publishing House, London.

Chirisa, I. \& Jonga, W., 2009, 'Urban local governance in the crucible: Empirical overtones of central government meddling in local urban councils affairs in Zimbabwe', Theoretical in Urban Management 12(1), 1-26.

Chirisa, I., 2000, 'Prospects for the asset-based community development approach in Epworth and Ruwa, Zimbabwe: A housing and environmental perspective', African Journal of History and Culture 1(2), 28-35.

Chirisa, I., 2013, 'Housing and stewardship in peri-urban settlements in Zimbabwe: A case study of Ruwa and Epworth', PhD thesis, University of Zimbabwe.

Chirisa, I., Dumba, S. \& Dube, B., 2013, 'Servicing the needs of inflating population at growth points in Zimbabwe? Spatio-temporal and economic considerations', Journal of Sustainable Development Studies 4(1), 36-52.

Davison, C.A., 2005, Urban governance and the effective delivery and management of infrastructure services in urban areas in Zimbabwe, Appraisal consultancy report of water and sewerage services delivered in Ruwa, Ruwa Local Board, Ruwa.

De Visser, J., Steytler, N. \& Machingauta, N., 2010, Local governance reform in Zimbabwe: A policy dialogue, Community Law Centre University of Western Cape, Cape Town.

Dickovick, J.T., 2011, Decentralisation and recentralisation in the developing world: Comparative studies from Africa and Latin America, Pennsylvania State University Press, University Park, PA.

Dillinger, W., 1994, Decentralisation and its implications for urban service delivery, World Bank, Washington, DC. https://doi.org/10.1596/0-8213-2792-5

Ding, C. \& Lichtenberg, E., 2009, 'Local officials as land developers: Urban spatial expansion in China', Journal of Urban Economics 66(1), 57-64. https://doi. org/10.1016/j.jue.2009.03.002

Freund, B., 2007, The African city: A history, Cambridge University Press, New York. https://doi.org/10.1017/СBO9780511618307

Hansen, N., 1972, 'Criteria for growth center policy', in A.R. Kuklinsky (ed.), Growth poles and growth centres in regional planning, Mouton, The Hague.

Hardoy, J.E., Cairncross, S. \& Satterthwaite (eds.), 1990, The poor die young: Housing and health in third world cities, Earthscan Publishers, London.

Hauser, P.M. \& Schnore, L.F. (eds.), 1967, The study of urbanisation, Wiley, New York.

Heath, R., 1978, 'Rhodesian service centres and service regions', MPhil dissertation, University of Rhodesia.

Helmsing, A.H.J., 1990, 'Transforming rural local government: Zimbabwe's postindependence experience', in N.D. Mutizwa-Mangiza \& A.H.J. Helmsing (eds.), Rural development and planning in Zimbabwe, Avebury Gower, Aldershot, 87-110. 
Howard, A.M., 2003, 'Cities in Africa, past and present: Contestation, transformation and discourse', Canadian Journal of African Studies 37(2/3), 197-235. https://doi. org/10.2307/4107238

Howman, R., 1969, 'Economic growth and community development in African areas', NADA 10(1), 3-8.

Jonga, W. \& Chirisa I., 2009, 'Urban local governance in the crucible: Empirical overtones of central government meddling in local urban councils affairs in Zimbabwe', Theoretical in Urban Management 12(3), 166-182.

Kapungu, L.T., 1973, The United Nations and economic sanctions against Rhodesia, Lexington Press, Lexington.

Kessides, C., 2006, The urban transition in Sub-Saharan Africa: Implications for economic growth and poverty reduction, World Bank, Washington, DC.

Kriger, N.J., 1992, Zimbabwe's guerrilla war: Peasants voices, Cambridge University Press, Cambridge.

Losman, D.S., 1978, 'Rhodesia: A decade under sanctions', Journal of Southern African Studies 43(2), 321-340.

Manyanhire, I.O., Mhishi, B., Svotwa, E. \& Sithole, N., 2009, 'Growth points or declining points? A case of Magunje Growth Point in Mashonaland West province of Zimbabwe', Journal of Sustainable Development in Africa 10(4), 506-520.

Marongwe, N., Mukoto, S. \& Chatiza, K., 2011, 'Scoping study: Governance of urban land markets in Zimbabwe', paper presented at the first Urban Land Mark Conference, 11-12 August 2010, Harare.

McKinnell, R., 1969, 'Sanctions and the Rhodesian economy', The Journal of Modern African Studies 7(4), 564-565. https://doi.org/10.1017/S0022278X0001884X

Mika, J., 2010, Sub national experiences of civic participatory in policy making and budgetary processes: The case of City of Gweru Zimbabwe, Municipal Finance Specialist, The Urban Institute, Gweru.

Mlambo, A.S., 1997, The economic structural adjustment programme: The case of Zimbabwe, 1990-1995, University of Zimbabwe Publications, Harare.

Mtisi, J., Nyakudya, M. \& Barnes, T., 2009, 'War in Rhodesia, 1965-1980', in B. Raftopoulos \& A.S. Mlambo (eds.), Becoming Zimbabwe: A history the pre-colonial period to 2008, pp. 115-140, Weaver Press, Harare.

Munzwa, K. \& Jonga, W., 2010, 'Urban development in Zimbabwe: Human settlement perspective', Theoretical and Empirical Research in Urban Management (5), 10 February, 120-145.

Muzorewa, T.T., 2012, 'An analysis of the contribution of the private sector in small town development: The case of Ruwa Town Zimbabwe', MA dissertation, Midlands State University.

Norcliffe, G., Freeman, D. \& Miles, N., 1984, 'Rural industrialization in Kenya', in E. Chuta \& S.V. Sethuraman (eds.), Rural small scale industries and employment in Africa and Asia, pp. 9-24, ILO, Geneva.

Nyandoro, M., 2007, 'Development and differentiation: The case of TILCO/ARDA irrigation activities in Sanyati (Zimbabwe) 1939-2000', PhD thesis, University of Pretoria.
Nyandoro, M., 2015, 'TILCOR-Sanyati irrigation: A case of development within the decentralisation policy context in colonial Zimbabwe, 1956-1980', Zambezia 42(1), 128-151.

Paradza, G., 2005, 'Reflections on Zimbabwe's past as building blocks for the future', Journal of Policy Issues and Actors 23(1), 1-12.

Patel, D., 1988, 'Some issues of urbanization and development in Zimbabwe', Journa of Social Development in Africa 3(2), 17-31.

Potts, D., 2000, 'Urban unemployment and migration in Africa: Evidence from Harare 1985-1994', Development and Change 31, 879-910. https://doi.org/10.1111/ 1467-7660.00181

Richardson, H.W., 1978, 'Growth centers, rural development and national urban policy: A defense', International Regional Science Review 3(2), 133-152. https:// doi.org/10.1177/016001767800300203

Rukuni, M., Schonker, S. \& Muzari, W., 1993, Rural industrialization in Zimbabwe: Potential constrains and strategies for development, University of Zimbabwe Publications, Harare.

Ruwa Local Board, 2011a, Final debit warning letters to Chakabva R. and Nyagura $P$, RLB, Ruwa.

Ruwa Local Board, 2011b, Ruwa Town Council at a Glimpse, Report from the Secretary, RLB, Ruwa.

Stren, R.E. \& White, R.R. (eds.), 1989, African cities in crisis, managing rapid urban growth, Westview Press, Boulder, CO.

Stren, R.E., 2004, 'Urban service delivery in Africa and the role of international assistance', Development Policy Review 32(1), 19-37. https://doi.org/10.1111/ dpr.12067

The Independent European Development Portal, viewed 24 January 2012, from http:// www.developmentportal.ed

Van Der Veen, M., 2009, Contracting for better places: A relational analysis of development agreements in urban development projects, IOS Press, Amsterdam.

Wekwete, K.H., 1987, 'Growth centre policy in Zimbabwe: A focus paper on district centres', Rural and Urban Planning (RUP) occasional paper (7), Department of Rural and Urban Planning, University of Zimbabwe, Harare.

Wekwete, K.H., 1988, 'Rural growth points in Zimbabwe - Prospects for the future', Journal of Social Development in Africa 3(2), 5-16.

Wekwete, K.H., 1991, 'Growth centre policy in Zimbabwe: With special reference to district service centers', in N.D. Mutizwa-Mangiza \& A.H.J. Helmsing (eds.), Rural development and planning in Zimbabwe, pp. 187-211 Avebury, Aldershot.

Wekwete, K.H., 1994, 'Urbanisation, urban development and management in Zimbabwe', in K.H. Wekwete \& C.O. Rambanepasi (eds.), Planning urban economies in southern and eastern Africa, pp. 13-28, Belmont, Avebury.

World Bank, 2013, Harnessing urbanisation to end poverty and boost prosperity in Africa, The World Bank, Washington, DC.

Zhou, G. \& Zvoushe, H., 2012, 'Public policy making in Zimbabwe: A three decade perspective', International Journal of Humanities and Social Sciences 2(8), 212-222. 